\title{
So what？と言われない研究をめざして
}

独计行政法人

座整技術総合研究所

人間福祉医工学研究部楻

㤠知的インターフェースグループ

北島 宗雄

研究グループ長

ヒューマンコンピュータインタラクションの分野で研究を始めて20㤰ほどになる。この分野は、コンピュータ

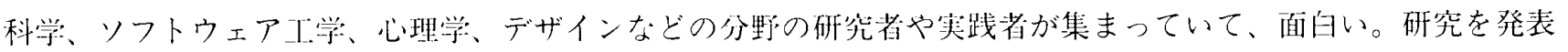
寸るときには、研究の意義がバックグラウンドの橽う人にとってもわかるようになっていることが必要だ。「それ でどうしたっていうの? 「「だからどうした？」「それで?」「確かにそのようにやればそうなるけど、それでなん の役に立つの?」これに答えられなければアウトだ。これは、間題がクリアで方法論も決まっている分野とはか なり異なっている。しかし、分野としての㧍间性ははっきりしている。この分野をリードする ACM SIGCHI 主 催の大会の抄録のタイトルが Human Factors in Computing Systems となっていることからもわかるように、 コンピュータシステムを人間側から見て使いやすいものにするというのがこの分野の活動の方向だ。

Austin Henderson がACM の雑誌 Interactionsでのインタビューで興味媣いことを述べている。Sowhat?

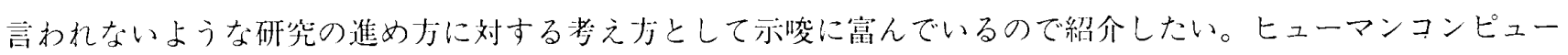

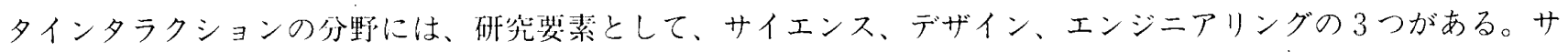
イエンスは「分解して検詩する」ものであり「われわれはどこにいるのか (where are we now?)」にこたえるも の、デザインは「心に描く」ものであり「どのようになりたいのか (where would we like to be?)」にこたえる もの、エンジニアリングは「笑行する」ものであり「目標をどのように達成するか (how do we get from here to there?)」にこたえるものである。そして、個々の破究者が全ての装素のエキスパートである必要はないが、開

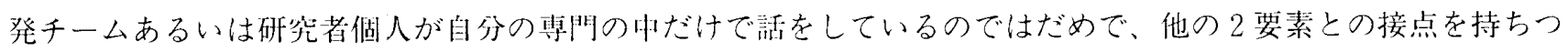
つ進めることが必要だ。これが彼の注張である。

インタラクティブなシステムを新たに開発する場合を考えてみよう。開発されるシステムは利用者である人間 の視点からデザインされなければならないが、この場命に彼の言うことをあてはめるとどうなるか。エンジニア リングの洒值観に扔いてはどのように实現するかが重琶だ。しかし、それだけではだめで、デザインの価值観か ら開発されるものを考えてみることも必琶だ。そのシステムによってわれわれの生活をどのようにしたいのか。 また、さらに考えを進めることも必装だろう。開発されるシステムで支援されるはずの人間活動はすでにほかの 手段で支㩖されているかもしれない。それは、必ずしもコンピュー夕を使ったものではなくローテクなものかも しれない。そのようなとき、開発されるシステムは睄存のものに取って代わってわれわれの生活にどのように入っ てくるのだろうか。これをしつかりと考えておくことはきわめて重装な゙。また、そのシステムを人間がどのよう に使うかをしっかりした人閫科学:の基礎の上で理解していることも必荘だ。

知能情報ファジイ学会で行われる研究にも、これらの3 装素が含まれていると思う。われわれはSoWhat?と言 われない研究をますます多く産出し、そして、豊かで思全で快適な人間生活を実現する上で欠くことのできない 分野として、確かな地位を築いていかなければならない。 